\title{
Tissue MicroArray (TMA) analysis of normal and persistent Chlamydophila pneumoniae infection Nicole Borel ${ }^{* \dagger 1}$, Sanghamitra Mukhopadhyay ${ }^{\dagger 2,5}$, Carmen Kaiser ${ }^{1}$, Erin D Sullivan ${ }^{2}$, Richard D Miller ${ }^{3}$, Peter Timms ${ }^{4}$, James T Summersgill2,3, Julio A Ramirez ${ }^{2}$ and Andreas Pospischil ${ }^{1}$
}

Address: ${ }^{1}$ Institute of Veterinary Pathology, Vetsuisse Faculty, University of Zurich, Zurich, Switzerland, ${ }^{2}$ Division of Infectious Diseases, Department of Medicine, University of Louisville, Louisville, Kentucky, USA, ${ }^{3}$ Department of Microbiology and Immunology, University of Louisville, Louisville, Kentucky, USA, ${ }^{4}$ Infectious Diseases Program, School of Life Sciences, Queensland University of Technology, Brisbane, Australia and ${ }^{5}$ Biological Defense Research Directorate, Naval Medical Research Center, 12300 Washington Avenue, Rockville, MD 20852, USA

Email: Nicole Borel* - n.borel@access.unizh.ch; Sanghamitra Mukhopadhyay - Mukhopadhyays.ctr.in@nmrc.navy.mil; Carmen Kaiser - c.kaiser@access.unizh.ch; Erin D Sullivan - edsull01@gwise.louisville.edu; Richard D Miller - rdmill01@louisville.edu; Peter Timms - p.timms@qut.edu.au; James T Summersgill - j.summersgill@louisville.edu; Julio A Ramirez - jarami01@gwise.louisville.edu; Andreas Pospischil - apos@vetpath.unizh.ch

* Corresponding author †Equal contributors

Published: 19 October 2006

BMC Infectious Diseases 2006, 6:152 doi:10.1186/147/-2334-6-152
Received: 01 June 2006

Accepted: 19 October 2006

This article is available from: http://www.biomedcentral.com/I47I-2334/6//52

(C) 2006 Borel et al; licensee BioMed Central Ltd.

This is an Open Access article distributed under the terms of the Creative Commons Attribution License (http://creativecommons.org/licenses/by/2.0), which permits unrestricted use, distribution, and reproduction in any medium, provided the original work is properly cited.

\begin{abstract}
Background: Chlamydophila pneumoniae infection has been implicated as a potential risk factor for atherosclerosis, however the mechanism leading to persistent infection and its role in the disease process remains to be elucidated.

Methods: We validated the use of tissue microarray (TMA) technology, in combination with immunohistochemistry (IHC), to test antibodies (GroEL, GroES, GspD, Ndk and Pyk) raised against differentially expressed proteins under an interferon-gamma (IFN- $\gamma$ ) induced model of chlamydial persistence.

Results: In the cell pellet array, we were able to identify differences in protein expression patterns between untreated and IFN- $\gamma$ treated samples. Typical, large chlamydial inclusions could be observed in the untreated samples with all antibodies, whereas the number of inclusions were decreased and were smaller and atypical in shape in the IFN- $\gamma$ treated samples. The staining results obtained with the TMA method were generally similar to the changes observed between normal and IFN- $\gamma$ persistence using proteomic analysis. Subsequently, it was shown in a second TMA including archival atheromatous heart tissues from 12 patients undergoing heart transplantation, that GroEL, GroES, GspD and Pyk were expressed in atheromatous heart tissue specimens as well, and were detectable morphologically within lesions by IHC.

Conclusion: TMA technology proved useful in documenting functional proteomics data with the morphologic distribution of GroEL, GroES, GspD, Ndk and Pyk within formalin-fixed, paraffinembedded cell pellets and tissues from patients with severe coronary atherosclerosis. The antibodies GroEL and GroES, which were upregulated under persistence in proteomic analysis, displayed positive reaction in atheromatous heart tissue from 10 out of 12 patients. These may be useful markers for the detection of persistent infection in vitro and in vivo.
\end{abstract}




\section{Background}

Chlamydophila (C.) pneumoniae is an obligate intracellular pathogen which causes both acute and chronic respiratory infections in humans [1-5]. Over the last decade, several reports in the literature have suggested that infection with C. pneumoniae may also contribute to the pathogenesis of atherosclerosis $[6,7]$. C. pneumoniae was detected in atheromatous lesions by isolation in pure culture, polymerase chain reaction (PCR), electron microscopy, in situ hybridization (ISH) and immunohistochemistry (IHC) [8-11]. In order to play a causative role in chronic diseases, C. pneumoniae would need to persist within infected tissue for extended periods of time, thereby stimulating a chronic inflammatory response.

In vitro, an alteration of the normal developmental cycle of C. pneumoniae can be induced by interferon- $\gamma$-mediated induction of the host cell indoleamine 2,3-dioxygenase (IDO) activity, leading to a persistent form of the organism [12-15]. In addition, several other models of in vitro persistence have been described (i.e. iron-limitation and antibiotics) [16]. Nevertheless, it is unknown which genes and proteins of $C$. pneumoniae are involved in the development and maintenance of persistence. We have previously characterized an IFN- $\gamma$ induced model of persistence by 2D gel electrophoresis [17-19], and identified several proteins that are differentially regulated during the induction of persistence.

Tissue microarray (TMA) technology, developed by Kononen et al., 1998 [20] represents a promising approach in the field of proteomics for its potential usefulness in in situ analysis. Preparations for TMA are constructed by obtaining cylindrical tissue specimens from paraffin blocks, assembling several hundreds into a single block, and preparing sections containing multiple tissue specimens [20-22]. TMA sections can be analyzed using standard pathology methods, such as hematoxylin and eosin (HE) staining or special stains and in situ analyses, such as immunohistochemistry (IHC) [20,21,23-25]. The utility of TMA protocols for high-throughput expression profiling of tumors at the molecular and protein levels has been widely used in human cancer research on formalinfixed and paraffin-embedded biopsy specimens $[20,21,26,27]$.

Since many markers of gene and protein expression are first established and studied in cell culture systems, it is useful to include cultured cells in TMAs for preliminary studies when translating experimental techniques from laboratory systems to studies of human tissue. Therefore, in the present study, we used 5 polyclonal antibodies directed against differentially regulated chlamydial proteins during in vitro persistence $[18,19]$ to validate the use of TMA technology on non-persistently, persistently infected and uninfected HEp-2 cell pellets. In addition, archival atheromatous heart tissues [10] were tested by TMA, in combination with IHC, using the same antibodies, to determine their potential future use in detecting persistently infected tissue.

\section{Methods \\ Cell line}

HEp-2 cells (ATCC CCL-23) were obtained from the American Type Culture Collection (Rockville, MD) and maintained in Iscove's Maintenance Medium (IMM) (Cellgro, Washington, DC), as described previously [28].

\section{Bacterial isolate}

C. pneumoniae A-03 (ATCC VR-1452), previously isolated from an atheroma of a patient with coronary artery disease during heart transplantation at the Jewish Hospital Heart and Lung Institute, Louisville, KY [10], were propagated in HEp-2 cell monolayers in Iscove's Growth Medium (IGM), as described previously [28]. Elementary bodies (EBs) were harvested and purified by disruption of HEp-2 cell monolayers with a cell scraper, sonication and centrifugation over a renografin density gradient [28]. EB suspensions were stored in sucrose-phosphate-glutamic acid buffer at $-80^{\circ} \mathrm{C}$, after which viable titers were established using standard methods.

\section{Patients specimens}

Archival atheromatous tissue specimens from twelve patients undergoing heart transplantation were investigated. Results from culture, PCR, IHC, ISH, EM and serology testing have been described previously [10]. The study of Ramirez et al. was approved by the Institutional Review Boards (IRB) at both the University of Louisville and Jewish Hospital Healthcare Corporation.

\section{Preparation of antibodies}

Five proteins were identified as being differentially regulated in the IFN- $\gamma$-induced model of persistence $[17,19]$ : (i) GroEL (60 kDa chaperonin) and (ii) GroES (10 kDa chaperonin) are both chaperons involved in protein folding, assembly and modification, (iii) GspD (general secretion protein D) involved in general protein secretion, (iv) $\mathrm{Ndk}$ (nucleoside-2-phosphate-kinase) involved in base and nucleotide metabolism of amino acid biosynthesis, and (v) Pyk (pyruvate kinase) involved in the energy metabolism (glycolysis and gluconeogenesis). GroEL was analysed and quantitated previously [17], and the remaining four proteins were selected and confirmed in an identical fashion [19]. GroEL and GroES were upregulated under persistence, whereas GspD and Pyk remained unchanged and Ndk was downregulated. Each protein was plugged from a silver-stained 2D gel, which was obtained from a purified EB preparation $[18,19,28]$, and used for antibody production of polyclonal antibodies at 
Harlan Bioproducts for Science, Inc. (Indianapolis, IN, USA). Pathogen-free, barrier-raised New Zealand white rabbits were immunized four times with the antigens, and sera from the final bleed were used in this study. The specificity of each antibody was confirmed in our laboratory by 2D gel electrophoresis of a purified C. pneumoniae EB preparation followed by western blot analysis, demonstrating specific reactivity on the blot which corresponded to the molecular weight and iso-electric point of each individual protein (data not shown).

\section{Other antibodies used}

The following antibodies were also used in these studies.

(i) Chlamydiaceae family-specific mouse monoclonal antibody directed against the chlamydial lipopolysaccharide (mLPS; Clone ACI-P, Progen, Heidelberg, Germany).

(ii) Chlamydiaceae family-specific rabbit polyclonal antibody directed against both the chlamydial LPS and the chlamydial major outer membrane protein (MOMP) (pLPS/MOMP; Cygnus Technologies, Inc., Southport, NC).

\section{TMA analysis}

Infection protocol

HEp-2 cells were grown in $75-\mathrm{cm}^{2}$ cell culture flasks (Costar, Cambridge, MA) to confluency and inoculated with purified C. pneumoniae EB $\left(1 \times 10^{9}\right.$ IFUs/flask $)$ in IGM with or without human recombinant IFN- $\gamma(50$ and $100 \mathrm{U}$ per $\mathrm{ml}$ ), followed by centrifugation at $675 \times g$ (Sorvall TR $6000 \mathrm{D}$ ) for $30 \mathrm{~min}$ at $10^{\circ} \mathrm{C}$ and incubating at $37^{\circ} \mathrm{C}$ in $5 \%$ $\mathrm{CO}_{2}$ for 24,48 and 72 hpi. After the respective incubation period, the medium was aspirated and the monolayers were washed twice with $1 \times$ phosphate buffer saline (PBS). Monolayers were fixed with $4 \%$ formalin in $1 \times$ PBS for 10 min followed by two washes with $1 \times$ PBS. All monolayers were harvested from the flasks with a cell scraper and transferred into $15 \mathrm{ml}$ of $1 \times$ PBS. After centrifugation at $675 \times g$ for $10 \mathrm{~min}$ at $20^{\circ} \mathrm{C}$, the supernatant was discarded. The pellets were re-suspended in 5\% BSA prepared in $1 \times$ PBS and transferred to an Eppendorf ${ }^{\mathrm{rM}}$ tube (Eppendorf-Netheler-Hinz GmbH, Hamburg, Germany) with one drop of hematoxylin for visualization. The cell suspensions were centrifuged for $5 \mathrm{~min}$ at $950 \times g$ and the supernatant was discarded. The resulting pellets were then embedded in paraffin using the Cytoblock ${ }^{\mathrm{TM}}$ cell block preparation system (Shandon ${ }^{\mathrm{TM}}$, Pittsburg, USA). For each condition (timepoints 24, 48 and $72 \mathrm{~h}$, concentrations of $50 \mathrm{U} / \mathrm{ml}$ and $100 \mathrm{U} / \mathrm{ml}$ of IFN- $\gamma$ ) four sets of infected monolayers were prepared. As controls, four sets of uninfected HEp-2 monolayers without and with $100 \mathrm{U} / \mathrm{ml}$ IFN- $\gamma$, were prepared as pellets.

\section{TMA setup}

Two equal cell culture array blocks including four equal prepared sets of cell pellets were created with the TMA Builder from Histopathology Ltd., Hungary according to the instructions of the manufacturer. Briefly, the recipient paraffin block with 24 holes of diameter $2 \mathrm{~mm}$ each arranged in four columns and six rows was moulded with the TMA Builder. The whole cell pellets from the donor blocks were punched out with the Paraffin-Punch-Extractor and were arrayed in the preformed recipient paraffin block according to protocol.

Formalin-fixed and paraffin-embedded coronary artery specimens were available from the 12 patients ( 1 to 7 paraffin blocks per patient). Three TMA blocks including each tissue of the 12 patients, an uninfected and an infected control HEp- 2 cell pellet (72 hpi, without IFN- $\gamma$ ) were created in an identical fashion. $4 \mu \mathrm{m}$ slide were cut using a standard microtome.

\section{Immunohistochemistry}

Paraffin sections were stained with the following primary anti-chlamydial-antibodies: (1) mLPS at a dilution of 1:50, (2) pLPS/MOMP at a dilution of 1:400, (3) GroEL, GroES, GspD, Ndk and Pyk at a dilution of 1:200. These optimal dilutions were previously determined. Detection was performed with the Detection Kit (Dako ChemMate ${ }^{\mathrm{TM}}$ Detection Kit, Glostrup, Denmark) according to the manufacturer's instructions. Antigen retrieval was performed by one min enzyme digestion (Pronase) (mLPS and pLPS/ MOMP) and microwave heating (750 W for 10 minutes) two times in citrate buffer ( $\mathrm{pH} 6,0$; Target Retrieval Solution ( $\times 10)$, Dako ChemMate ${ }^{\mathrm{TM}}$, Glostrup, Denmark) (GroEL, GroES, GspD, Ndk and Pyk), respectively. For inhibition of the endogenous peroxidase activity, the slides were immersed in peroxidase-blocking solution (Dako ChemMate $^{\mathrm{TM}}$, Glostrup, Denmark) for $5 \mathrm{~min}$ at room temperature (RT). Two additional blocking solutions were added to the slides, which were incubated with the polyclonal antibodies GroEL, GroES, GspD, Ndk and Pyk: Dako Protein Block Serum-free for $5 \mathrm{~min}$ at room temperature (Dako ChemMate ${ }^{\mathrm{TM}}$, Glostrup, Denmark) and 20 min Avidin D solution followed by 20 min Biotin solution at room temperature (Vector). The slides were incubated with the primary antibody for $60 \mathrm{~min}$ (mLPS and pLPS/MOMP) or over night (GroEL, GroES, GspD, $\mathrm{Ndk}$ and Pyk) at room temperature in a moist chamber. In total, the IHC for each antibody was repeated at least four times on consecutive sections.

\section{Results \\ Cell pellet array}

Results with the monoclonal antibody directed against LPS (mLPS) and the polyclonal antibody directed against chlamydial LPS and MOMP (pLPS/MOMP) were similar. 
Typical large, uniformly-staining chlamydial inclusions, located near the host cell nucleus, could be seen at 48 and 72 hpi in the untreated samples with the mLPS (Figure 1) and the pLPS/MOMP antibody. Results with the 5 polyclonal antisera tested, showed similar staining patterns in the untreated samples, however, not all inclusions were stained uniformly positive (Figure 1). Earlier in the chlamydial developmental cycle at $24 \mathrm{~h}$, granular positive material was seen in the cytoplasm of untreated cell pellets with the mLPS antibody and the pLPS/MOMP antibody, as well as the GroEL, GroES and Pyk antibodies, and to a lesser extent, with the GspD (data not shown). All pellets at 24 hpi were negative with the Ndk antibody.

The IFN- $\gamma$-treated samples displayed an overall decrease in positive reactivity. At 48 and $72 \mathrm{hpi}$, the number of inclusions were decreased and were obviously smaller and atypical in morphology (Figure 1). This could be observed for all antibodies, except for Ndk, which was negative in all IFN- $\gamma$-treated samples (Figure 1). There was no difference in inclusion morphology and antibody staining patterns seen between the two concentrations of IFN- $\gamma$ (50 U/ $\mathrm{ml}$ or $100 \mathrm{U} / \mathrm{ml}$ ). Overall, the assay showed good reproducibility in all four replicates of monolayers.

\section{TMA with atheromatous heart tissues}

Granular, positive-staining material was seen in the cytoplasm of subintimal macrophages and smooth muscle cells in the medial part of the affected coronary arteries of all patients with at least one antibody, except the two patients with negative results for the presence of $C$. pneumoniae in the original study (patients \# 7 and 11) [10]. Patients \# 10 and 12 were positive with all antibodies used except of the Ndk, which was negative in all 12 heart tissue specimens. Patients \# 1, 2, 3 and 9 were positive with the GroEL, GroES, GspD and Pyk, whereas patients \# 4 and 6 were only positive with the GroEL, GspD and Pyk. Patient \# 5 was positive with the GroES and Pyk, and patient \# 8 revealed positive reaction with the GroEL and GspD. All patients were negative when tested with the mLPS, whereas the pLPS/MOMP ab revealed positive reactions in patients \# 10 and 12.

Positive staining of the antibodies GroEL and GroES in patient \# 10 and GspD and Pyk in patient \# 12, respectively, is displayed in figure 2.

\section{Discussion}

In this study, TMA technology was useful in documenting functional proteomics data showing the morphologic distribution of GroEL, GroES, GspD, Ndk and Pyk within formalin-fixed, paraffin-embedded cell pellets and atheromatous heart tissues. GroEL, GroES, GspD, Ndk and Pyk, selected as differentially regulated proteins from proteomic analysis, were expressed in C. pneumoniae- infected, untreated and IFN- $\gamma$ treated HEp-2 cells and atheromatous heart tissues and were detectable morphologically by IHC. In general, IHC allows the detection of the presence of an antigen in tissue sections, however, the intensity of antigen labelling does not correlate with the amount of antigen present. The IHC labelling evaluated in this study, therefore, represents the presence or absence of proteins, but does not reflect quantitative expression of GroEL, GroES, GspD, Ndk, Pyk, mLPS and/or pLPS/ MOMP.

By using cell pellet array, in combination with IHC, it was possible to identify the number, size and morphology of the chlamydial inclusions. Numbers of inclusions at 48 hpi and 72 hpi were decreased under IFN- $\gamma$-persistence and the inclusions were smaller and atypical, as described previously [15], however, the staining intensity remained the same as that seen in untreated cells.

The staining results obtained with the TMA method were generally similar to the changes observed between normal and IFN- $\gamma$ persistence using proteomic analysis [17-19]. For example, GroEL, which was upregulated in proteomic analysis, displayed more positive reactions in the IFN- $\gamma$ treated samples when compared to GspD, which remained unchanged in the proteomic analysis. Likewise, $\mathrm{Ndk}$ reactivity remained negative in all IFN- $\gamma$-treated samples by TMA, which corresponded to the downregulation observed in the proteomic analysis.

In comparison to other methods, such as PCR, we were able to localize and visualize the positive reactions within the atheromatous heart tissue by TMA, in combination with IHC. The TMA method allowed a comparison between multiple cell pellets or tissue specimens on one microscope slide. The $2 \mathrm{~mm}$ punch, in combination with the Tissue Microarray Builder allowed easy manipulation during punching, facilitating a rapid preparation of the cell culture array block. The fact that the $2 \mathrm{~mm}$ punch can cause significant damage to the donor block was not of importance because each donor block contained only one single cell pellet that was entirely punched out and the whole area of each pellet could be examined. Other punch sizes such as $0.6 \mathrm{~mm}$ and $1.2 \mathrm{~mm}$ cause less damage to the original donor block and make it possible to array several hundreds of specimens on one single block, however the creation of this block is more laborious. The problem of reduction of the amount of tissue analyzed from the whole cell pellet to a disk, which may be not be representative of the protein expression of the entire tissue specimen, can be solved by performing the experiments in several-fold redundancy. For that reason, we created two equal cell pellet blocks including four sets of equally prepared monolayers containing the three timepoints (treated and untreated cell pellets and negative controls). 
A
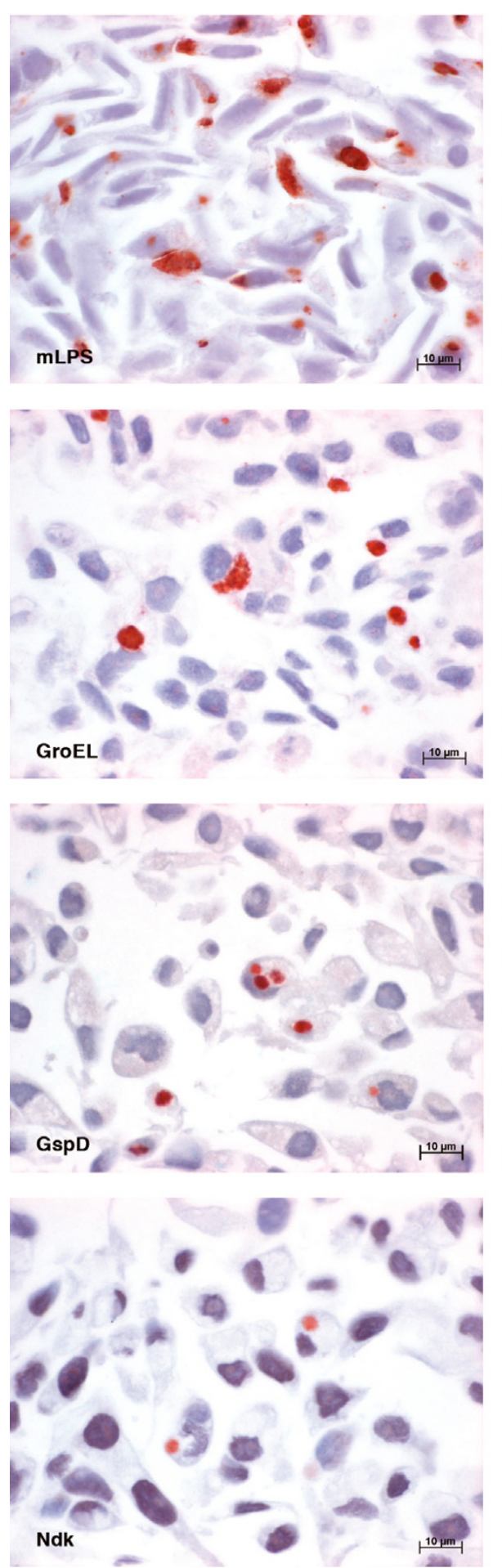

B
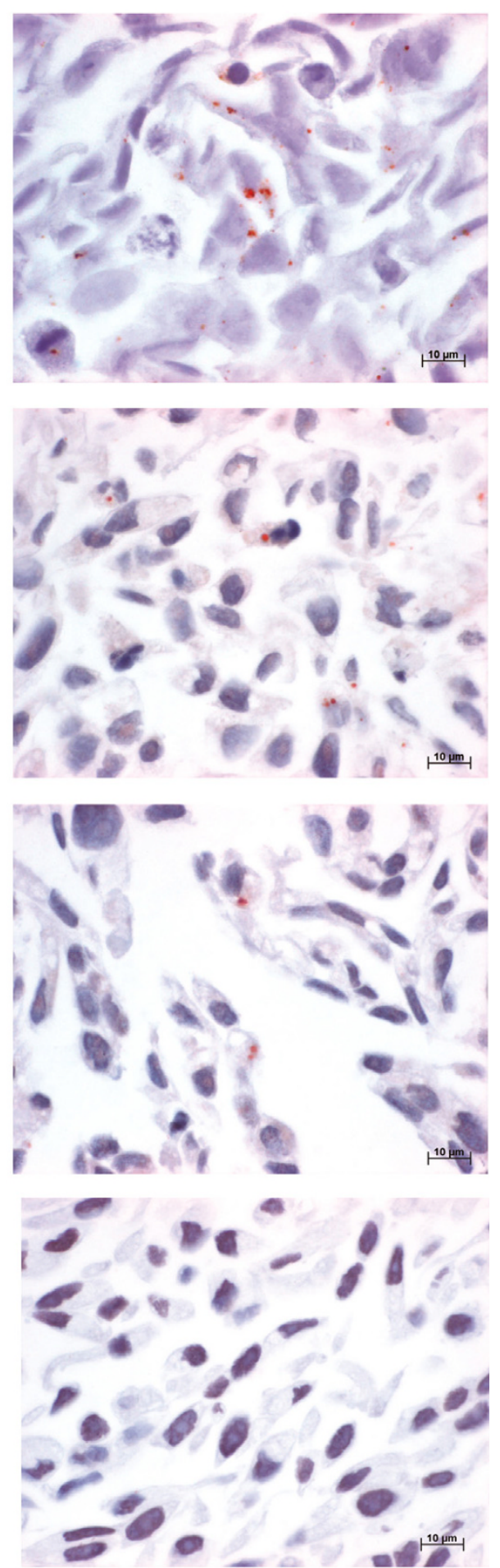

Figure I

cell pellet array. Photomicrographs of TMA preparations of whole cell pellets showing differential expression pattern of $C$. pneumoniae proteins under untreated (A) and $50 \mathrm{U} / \mathrm{ml} \mathrm{IFN}-\gamma$ treated (B) conditions at $48 \mathrm{hpi}$. Representative monolayers are shown to depict distinct differences in morphology and size of inclusions, as they were smaller and atypical under IFN- $\gamma$ induced persistence in comparison to the untreated monolayers. 

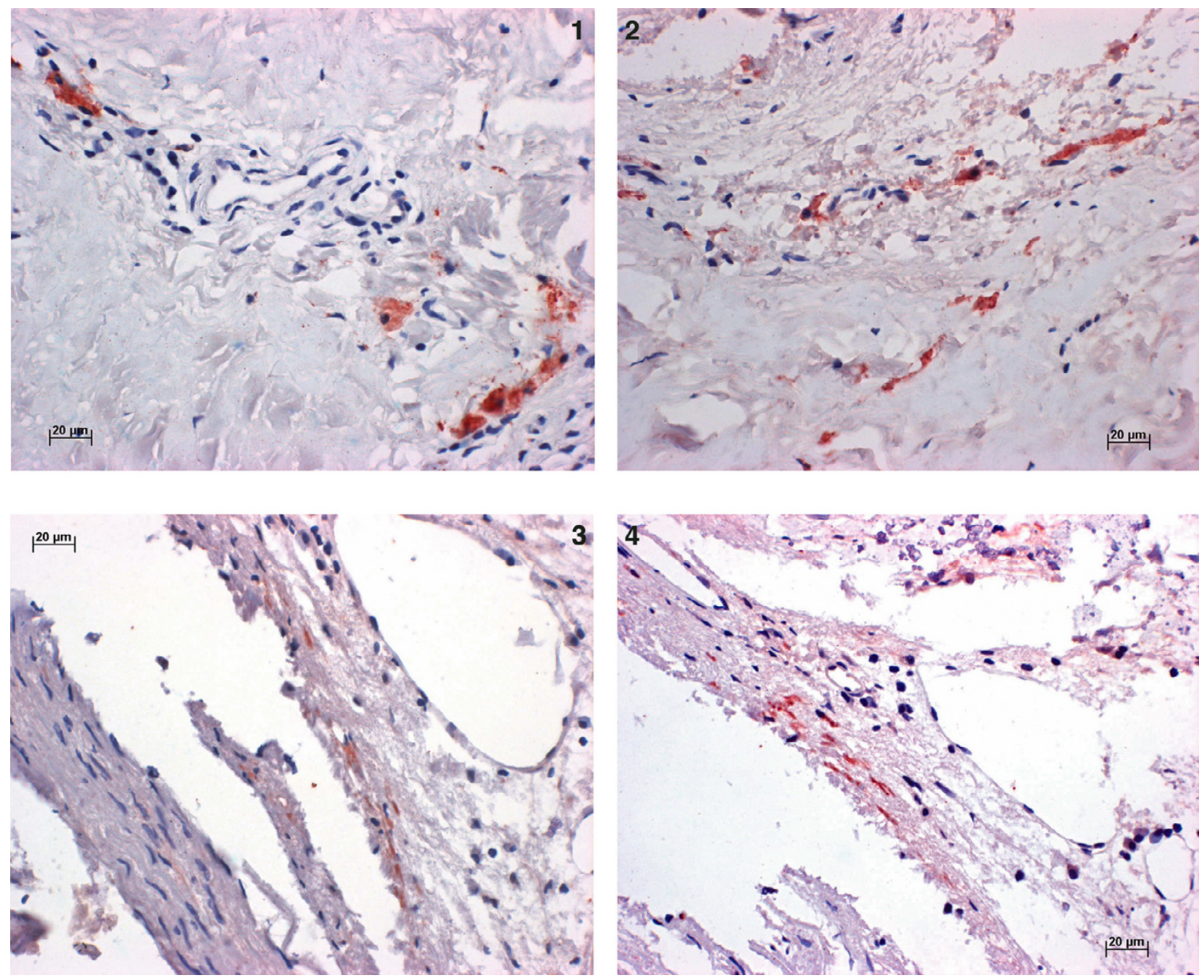

Figure 2

TMA with atheromatous heart tissues. Photomicrographs of TMA preparations of atheromatous heart tissues of patient \# 10 showing positive reaction within macrophages with GroEL (I) and with GroES (2) and in patient \# 12 showing positive reaction within smooth muscle cells with GspD (3) and Pyk (4).

Multiple sections of the two TMA blocks were cut and probed with each antibody.

Multiple sections of 3 TMA blocks, including the atheromatous heart tissue, were investigated with each antibody. In our previous study, patients \# 1, 2, 3, 6 and 12 were positive by IHC using Chlamydia-specific and C. pneumoniae-specific antibodies [10]. We were able to detect 5 more positive patients with experimentally produced antiGroEL, anti-GroES, anti-GspD and anti-Pyk antibodies. Thus, differentially regulated proteins by proteomic analysis were expressed in C. pneumoniae-infected human atheromatous heart tissue specimens and were detectable morphologically within lesions by IHC. The staining results obtained with the TMA corresponded to the reactivity as determined by proteomic analysis, for example, GroEL and GroES, which were upregulated under persistence in proteomic analysis, were likewise positive in most heart tissue specimens. Patients \# 7 and 11, which underwent heart transplantation primarily due to myocarditis, rather than severe atherosclerosis (unpublished data), displayed questionable positive results (GroEL, GroES, GspD and Pyk). As these 2 patients were in fifth decade of life and had elevated anti-C. pneumoniae titers in the microim- 
munofluorescence assay [10], we tend to assume that they suffered from atherosclerosis and were Chlamydiainfected as patients \# 1-6, 10 and 12, but perhaps to a lesser extent. Definitive demonstration of chlamydial particles in patients \# 7 and 11 by more sensitive techniques (i.e. ultrastructural studies) is in progress [29].

\section{Conclusion}

Overall, GroEL and GroES tend to be useful markers to detect persistent infection in vitro and in vivo. In addition, GspD and Pyk antibodies gave similar reactivity, indicating appropriate sensitivity and specificity, and may also allow the detection of $C$. pneumoniae in chronicallyinfected tissue. Antibody prepared against Ndk remained negative in tissue specimens from all 12 archived atheromatous tissue specimens, which corresponded nicely to the downregulation observed in proteomic analysis. These data represent the first thorough examination of atheromatous tissue by experimentally produced antibodies against $C$. pneumoniae and may provide a useful technique to further define the role of this organism in atherosclerosis and other chronic human diseases.

\section{Competing interests}

The author(s) declare that they have no competing interests.

\section{Authors' contributions}

NB carried out the TMA analysis and drafted the manuscript. SM performed the cell culture infections and the 2 D gel electrophoresis. CK performed the IHC. EDS participated in the cell culture infections and 2 D gel electrophoresis. RDM and PT participated in the coordination of the study and helped to draft the manuscript. JTS and AP participated in the design of the study. JAR provided the atheromatous heart tissue specimens. All authors read and approved the final manuscript.

\section{Acknowledgements}

We would like to thank Dr. Urs Ziegler and Claudia Dumrese, from the Institute of Anatomy, University of Zurich, Switzerland, for providing C. pneumoniae-infected HEp2 cells. This work was supported by grants from the NHMRC (PT) and the National Institutes of Health (HL68874 and AI5I255) (JTS).

\section{References}

I. Grayston JT, Kuo CC, Wang SP, Altman J: A new Chlamydia psittaci strain, TWAR, isolated in acute respiratory tract infections. N Eng J Med 1986, 3 I5:161-168.

2. Grayston JT: Infections caused by Chlamydia pneumoniae strain TWAR. Clin Infect Dis 1992, 15:757-763.

3. Hammerschlag MR, Chirgwin K, Roblin PM, Gelling M, Dumornay W, Mandel L, Smith P, Schachter J: Persistent infection with Chlamydia pneumoniae following acute respiratory illness. Clin Infect Dis 1992, I4:178- I82.

4. Kuo CC, Jackson LA, Campbell LA, Grayston JT: Chlamydia pneumoniae (TWAR). Clin Microbiol Rev 1995, 8:45I-46I.

5. Peeling RW, Brunham RC: Chlamydiae as pathogens: new species and new issues. Emerg Infect Dis 1996, 2:307-319.
6. Saikku P, Mattila K, Nieminen MS, Makela PH, Huttunen JK, Valtonen $\checkmark$ : Serological evidence of an association of a novel Chlamydia, TWAR, with chronic coronary heart disease and acute myocardial infarction. Lancet 1988, ii:983-986.

7. Saikku P, Leinonen M, Tenkanen L, Ekman MR, Linnanmaki E, Manninen V, Manttari M, Frick MH, Huttunen JK: Chronic Chlamydia pneumoniae infection as a risk factor for coronary heart disease in the Helsinki Heart Study. Ann Intern Med 1992, I 16:273-278.

8. Kuo CC, Shor A, Campbell LA, Fukushi H, Patton DL, Grayston JT: Demonstration of Chlamydia pneumoniae in atherosclerotic lesions of coronary arteries. J Infect Dis 1993, 167:84I-849.

9. Campbell LS, O'Brien ER, Cappuccio AL, Kuo CC, Wang SP, Stewart D, Patton DL, Cummings PK, Grayston JT: Detection of Chlamydia pneumoniae TWAR in human coronary atherectomy tissues. J Infect Dis 1995, 172:585-588.

10. Ramirez JA, Ahkee S, Summersgill JT, Ganzel BL, Ogden LL, Quinn TC, Gaydos CA, Bobo LL, Hammerschlag MR, Roblin PM, LeBar W, Grayston JT, Kuo CC, Campbell LA, Patton DL, Dean D, Schachter J: Isolation of Chlamydia pneumoniae from the coronary artery of a patient with coronary atherosclerosis. Ann Intern Med 1996, 125:979-982.

II. Jackson LA, Campbell LA, Kuo CC, Rodríguez KI, Lee A, Grayston JT: Isolation of Chlamydia pneumoniae from a carotid endarterectomy specimen. J Infect Dis 1997, 176:292-295.

12. Summersgill JT, Sahney NN, Gaydos CA, Quinn TC, Ramirez JA: Inhibition of Chlamydia pneumoniae growth in HEp-2 cells pretreated with gamma interferon and tumor necrosis factor alpha. Infect Immun 1995, 36:280I-2803.

13. Holmes EW: Expression and regulation of interferon-gammainduced tryptophan catabolism in cultured skin fibroblasts. J Interferon Cytokine Res 1998, I8:509-520.

14. Mehta SJ, Miller RD, Ramirez JA, Summersgill JT: Inhibition of Chlamydia pneumoniae replication in HEp-2 cells by interferon- $\gamma$ : role of tryptophan catabolism. J Infect Dis 1998, 177:1326-1331.

15. Pantoja LG, Miller RD, Ramirez JA, Molestina RE, Summersgill JT: Characterization of Chlamydia pneumoniae persistence in HEp-2 cells treated with gamma interferon. Infect Immun 200I, 69:7927-7932.

16. Hogan RJ, Mathews SA, Mukhopadhyay S, Summersgill JT, Timms P: Chlamydial persistence: beyond the biphasic paradigm. Infec Immun 2004, 72: I843-I855.

17. Molestina RE, Klein JB, Miller RD, Pierce WH, Ramirez JA, Summersgill JT: Proteomic analysis of differentially expressed Chlamydia pneumoniae genes during persistent infection of HEp-2 cells. Infect Immun 2002, 70:2976-298I.

18. Mukhopadhyay S, Miller RD, Summersgill JT: Analysis of altered protein expression patterns of Chlamydia pneumoniae by integrated Proteome-Works System. J Proteome Res 2004, 3:878-883.

19. Mukhopadhyay S, Miller RD, Sullivan ED, Theodoropoulos C, Mathews SA, Timms P, Summersgill JT: Protein expression profiles of Chlamydia pneumoniae: persistent vs. heat shock stress response. Infect Immun in press.

20. Kononen J, Bubendorf L, Kallioniemi A, Barlund M, Schraml P, Leighton S, Torhorst J, Mihatsch MJ, Sauter G, Kallioniemi OP: Tissue microarrays for high-throughput molecular profiling of tumor specimens. Nat Med 1998, 4:844-847.

21. Bubendorf L: High-throughput microarray technologies: from genomics to clinics. Eur Urol 200I, 40:23I-238.

22. Bubendorf L, Nocito A, Moch H, Sauter G: Tissue microarray (TMA) technology: miniaturized pathology archives for highthroughput in situ studies. J Pathol 200I, 195:72-79.

23. Moch $\mathrm{H}$, Kononen $\mathrm{T}$, Kallioniemi OP, Sauter $\mathrm{G}$ : Tissue microarrays: what will they bring to molecular and anatomic pathology? Adv Anat Pathol 200I, 8: 14-20.

24. Simon R, Mirlacher M, Sauter G: Tissue microarrays. Biotechniques 2004, 36:98-105.

25. Van De Rijn M, Gilks CB: Applications of microarrays to histopathology. Histopathology 2004, 44:97- 108.

26. Schraml P, Kononen J, Bubendorf L, Moch H, Bissig $H$, Nocito A, Mihatsch MJ, Kallioniemi OP, Sauter G: Tissue microarrays for gene amplification surveys in many different tumor types. Clin Cancer Res 1999, 5: 1966-1975. 
27. Camp RL, Charette LA, Rimm DL: Validation of tissue microarray technology in breast carcinoma. Lab lnvest 2000, 80:1943-1949.

28. Mukhopadhyay S, Clark AP, Sullivan ED, Miller RD, Summersgill JT: Detailed protocol for the purification of Chlamydia pneumoniae elementary bodies. J Clin Microbiol 2004, 42:3288-3290.

29. Borel N, Summersgill JT, Mukhopadhyay S, Kaiser C, Nufer L, Miller RD, Ramirez JA, Pospischil A: Persistent Chlamydophila pneumoniae in human coronary atherosclerotic tissue: Tissue Microarray (TMA) analysis and ultrastructural study. In Proceedings of the Eleventh International Symposium on Human Chlamydial Infections: 18-23 June 2006; Niagara-on-the-Lake, Ontario, Canada Edited by: Max Chernesky, Harlan Caldwell, Gunna Christiansen, lan N Clarke, Bernhard Kaltenboeck, Charles Knirsch, Cho-Chou Kuo, James Mahony, Roger G Rank, Pekka Saikku, Julius Schachter, Walter E Stamm, Richard S Stephens, James T Summersgill, Peter Timms, Priscilla B Wyrick. San Francisco, CA 94II0, USA; 2006:567-570.

\section{Pre-publication history}

The pre-publication history for this paper can be accessed here:

http://www.biomedcentral.com/1471-2334/6/152/pre

pub

Publish with Bio Med Central and every scientist can read your work free of charge

"BioMed Central will be the most significant development for disseminating the results of biomedical research in our lifetime. "

Sir Paul Nurse, Cancer Research UK

Your research papers will be:

- available free of charge to the entire biomedical community

- peer reviewed and published immediately upon acceptance

- cited in PubMed and archived on PubMed Central

- yours - you keep the copyright

Submit your manuscript here:

http://www.biomedcentral.com/info/publishing_adv.asp 